Research Article / Araştırma Makalesi

Geliş tarihi: 10.02.2016

Kabul tarihi: 24.03.2016
Harran Tarım ve Gıda

Bilimleri Dergisi

(2016) 20(1): 1-6

\title{
Evaluation of Fluoride Concentration and Daily Intake by Human from Tea Infusions
}

\author{
Ayse Dilek ATASOY ${ }^{1}$, M. Irfan YESILNACAR ${ }^{1}$, Ahmet Ferit ATASOY ${ }^{*}$ \\ ${ }^{1}$ Faculty of Engineering, Department of Environmental Engineering, Harran University, Sanlıurfa, Turkey \\ ${ }^{2}$ Faculty of Agriculture, Department of Food Engineering, Harran University, Sanliurfa, Turkey \\ *Corresponding author: fatasoy@harran.edu.tr; Tel: +90 4143183732
}

\begin{abstract}
The objectives of this study were to determine the fluoride content of tea and the percentage of the average daily intake of fluoride from tea extracts after $10 \mathrm{~min}$ brewing. The fluoride content in infusion of commercially available Turkish and Ceylon black, green teas were determined by ion selective electrode. The content of fluoride in tea infusion ranged from 1.010 to $2.89 \mathrm{mg} \mathrm{L}^{-1}$. The fluoride concentrations determined in Turkish black and green tea infusion were higher than in Ceylon black and green tea. The intake of fluoride will be in the range of 30.2-50.0\% and 48.3-80.0\% for adult and children-teenagers tea drinkers respectively, consuming ten glasses or five cups $(1000 \mathrm{ml})$ of black tea per day. People are often exposed to multiple sources of fluoride, such as in food, water, air and excessive use of toothpaste. The control of tea quality is important to protect the human against to too high uptake of this element from black tea, which is the most popular beverage in Turkey. Excessive intake of fluoride with black tea, especially in the regions with its high level in the drinking water, increases the risk of dental fluorosis in children during the years of tooth development.
\end{abstract}

Keywords: Tea infusion, Fluoride, Black tea, Green tea

\section{Demlenmiş Çayların Florür Miktarlarının ve Günlük Florür Alımının Belirlenmesi}

Öz

Bu çalışmanın amacı Türk ve Seylan siyah ve yeşil çaylarının 10 dakika demlendikten sonraki Florür miktarlarını ve bu miktarların günlük flor intiyacını karşılama oranlarını ion selektif elektrot kullanarak belirlemektir. Demleme sonrası çayların florür miktarları 1.010 ile $2.89 \mathrm{mg} \mathrm{L}^{-1}$ arasında değişmiştir. Siyah ve yeşil Türk çaylarının florür miktarlarının Seylan çaylarından daha yüksek olduğu belirlenmiştir. Yetişkin ve çocuk bir birey günde $1000 \mathrm{ml}$ siyah çay (10 bardak veya 5 fincan) tükettiğinde sırasıyla günlük florür intiyacının \%30.2-50.0 ve \%48.3-80.0'ini karşılayacaktır. İnsanlar gıda, su, hava ve diş macunları gibi farklı kaynaklardan florür almaktadırlar. Bu nedenle, özellikle sularında fazla miktarda florür bulunan bölgelerde, çocuklar gelişme dönemlerinde florisis riski ile karşı karşıyadır.

Anahtar kelimeler: Çayın demlenmesi, Florür, Siyah çay, Yeşil çay

\section{Introduction}

Tea plant is a perennial evergreen plant with three races viz. Camellia sinensis var. sinensis, Camellia sinensis var. assamica and Camellia sinensis var. cambodiensis. Tea plant grows best in tropical and subtropical areas having adequate rainfall, good drainage and acid soils (Karak and Bhagat, 2010). Tea is cultivated in an area of 762008 ha in Turkey (Anonymous, 2015). The annual production of tea in Turkey and world were 212400 and 5345523 tones, respectively, (Anonymous, 2014). According to production techniques, tea is classified into six main types like white, 
green, yellow, oolong, black and postfermented tea. Polyphenols have antioxidative, antimutagenic and anticarcinogenic effects which are the most biologically active group of tea components. Additionally, tea has beneficial to human health compounds which like fluoride, caffeine and essentials minerals (Cabrera et al., 2003; Yao et al., 2004). Tea drinking is associated with the reduction of serum cholesterol, prevention of low density lipoprotein oxidation, decreased risk of cardiovascular disease and cancer (Chung et al., 2003).

Fluorine (F) is an important trace element to human and animal health, and fluorine is present in the Earth crust only in compounds form due to its reactivity (Wang and Liang, 2012). The total amount of fluorine ranges from $3.5 \mathrm{~g}$ to $4.0 \mathrm{~g}$. Most of the total body fluorine is present in bones and teeth in the form of hydroxyfluoroapatite. In teeth, fluorine is built into both dentine and enamel. The amount of fluorine in the body depends upon the fluorine intake from food and/or beverages, the age, gender, and some other factors. The fluorine concentration of young (20-30 years old) and old (70-80 years old) people in the bones on the dry matter are 200-800 mg kg-1 and 1000-2500 mg kg-1, respectively. In the blood, fluorine is present predominately in its inorganic form and its average concentration ranges from $10 \mu \mathrm{g} \mathrm{I}^{-1}$ to $200 \mathrm{\mu g} \mathrm{L}^{-1}$ (Sucman and Bednar, 2012).

Tea (Camellia sinensis) is widely consumed across the world owing to its healthy and biological effects. However, tea is a fluorine accumulator and $\mathrm{F}$ content in mature tea leaves are 1000 times higher than watersoluble $\mathrm{F}$ level in the soil on which it is grown (Fung et al., 1999; Wang and Liang, 2012). Tea leaf is the major organ accumulating $F$ and the $F$ in tea leaf is nearly $98 \%$ of $F$ accumulated in tea plant (Wong et al., 2003; Wang and Liang, 2012). Tea drinking is considered to be a source of $\mathrm{F}$ intake in human dietary. However, epidemiological observations showed that fluorosis was related to long-term consumption of teas containing high levels of fluorine in some inhabitants in the west of China, Turkey and other parts of the world where tea was traditionally consumed (Sofuoglu and Kavcar, 2008; Wang and Liang, 2012). The objectives of the present study were: 1) to determine the fluoride concentration in tea samples consumed in Sanlıurfa exclusively, by potentiometric measurement using a fluoride ion-selective electrode in tea infusions and 2) to evaluate the percentage of the average daily intake of fluoride from tea extracts after $10 \mathrm{~min}$ of brewing.

\section{Materials and Methods}

\section{Sample collection}

Fifteen tea leave samples were purchased from supermarkets in Sanlıurfa in 2012. Seven tea samples were assured from CAYKUR in 2012. All these samples correspond to the brands most commonly consumed in Turkey. The studied teas include 19 black (3 Ceylon, 16 Turkish teas), 3 green (1 Ceylon, 2 Turkish teas) teas.

\section{Preparation of tea infusions}

The method commonly used for preparation of tea beverage was adopted for this study to assess the actual amount of elemental intake in the human body by drinking this beverage. Before tea infusion, all of the samples were heated at $60{ }^{\circ} \mathrm{C}$ for 3 hours. Tea infusions were prepared as follows: $2.00 \mathrm{~g}$ of tea was carefully weighed into glass beakers. One hundreds milliliters of boiled distilled water was poured into the glass beakers after which they were covered 
by watch glasses to extract the components of tea leaves. After $10 \mathrm{~min}$, the extracted solution (tea infusion) was filtered through filter paper (Whatman 42, $125 \mathrm{~mm}$ ) into test tubes and analyzed immediately. Tea infusion for each samples repeated two times on different days.

\section{Measurement of fluoride contents}

Fluoride analyses were performed by Hach-Lange HQ40d multi-measurement device (Fluoride Meter - product code: 2589 99) by TISAB (total-ionic strength adjustment buffer) method (Liu et al., 2010). Fluoride measurement using ion selective electrode is suggested by EPA, APHA and ASTM (APHA, 1998). All analyses were performed in duplicate.

\section{Results and Discussion}

\section{Fluoride extraction into tea infusions}

The fluoride content of tea samples after infusion is listed in Table 1. The content of fluoride in tea infusion ranged from 1.010 to $2.89 \mathrm{mg} \mathrm{L}^{-1}$. The highest level was obtained for the infusion of organic Turkish black tea (sample 16) and the lowest one was found in extract of Ceylon green tea (sample 22). The obtained concentrations are comparable with those reported by the authors (Chan and Koh, 1996; Hayacibara et al., 2004; Malinowski et al., 2008).

The mean fluoride content of Turkish (15 samples) and Ceylon black tea (3 samples) were determined $1.687 \mathrm{mg} \mathrm{L}^{-1}$ and $1.136 \mathrm{mg}$ $\mathrm{L}^{-1}$, respectively. In general, the fluoride concentrations determined in Turkish black and green tea infusion were higher than in Ceylon black and green tea, except sample 12 . These results may be due to properties of soil, age of tea plant, and also maturity of tea leaves. Emekli-Alturfan et al. (2009) expressed that fluoride content of black tea samples originally produced in Turkey are higher than produced in Sri Lanka, India and Kenya. Fluoride is selectively absorbed from the soil to the tea tree and exists in tea leaf. Especially acidic soils are responsible to accumulation of fluoride in tea plant. Fluoride levels in leaves and stems increase with the age of the plant. $F$ content in mature tea leaves is higher than water-soluble $\mathrm{F}$ level in the soil on which it is grown (Fung et al., 1999).

Table 1. Fluoride concentrations in tea infusions after $10 \mathrm{~min}$ brewing ( $\mathrm{mg} \mathrm{L}^{-1}$ )

Çizelge 1. 10 dakika demlenme sonrası çayların florür miktarları

\begin{tabular}{|c|c|c|}
\hline $\begin{array}{l}\text { Sample } \\
\text { No } \\
\text { Örnek } \\
\text { No }\end{array}$ & $\begin{array}{l}\text { Tea Properties } \\
\text { Çay Çeşidi }\end{array}$ & $\begin{array}{c}\text { Fluoride } \\
\text { Contents } \\
\text { Florür Içeriği }\end{array}$ \\
\hline 1 & Turkish Black Tea & $2.000 \pm 0.01$ \\
\hline 2 & Turkish Black Tea & $1.670 \pm 0.01$ \\
\hline 3 & Turkish Black Tea & $1.517 \pm 0.02$ \\
\hline 4 & Turkish Black Tea & $1.743 \pm 0.07$ \\
\hline 5 & Turkish Black Tea & $1.950 \pm 0.02$ \\
\hline 6 & Turkish Black Tea & $1.680 \pm 0.03$ \\
\hline 7 & Turkish Black Tea & $1.607 \pm 0.04$ \\
\hline 8 & Turkish Black Tea & $1.207 \pm 0.07$ \\
\hline 9 & Turkish Black Tea & $1.617 \pm 0.01$ \\
\hline 10 & Turkish Black Tea & $1.937 \pm 0.03$ \\
\hline 11 & Turkish Black Tea & $1.897 \pm 0.04$ \\
\hline 12 & Turkish Black Tea & $1.427 \pm 0.00$ \\
\hline 13 & Turkish Black Tea & $1.627 \pm 0.01$ \\
\hline 14 & Turkish Black Tea & $1.647 \pm 0.03$ \\
\hline 15 & Turkish Black Tea & $1.790 \pm 0.01$ \\
\hline 16 & $\begin{array}{c}\text { Organic Turkish } \\
\text { Black Tea }\end{array}$ & $2.890 \pm 0.04$ \\
\hline 17 & Ceylon Black Tea & $1.050 \pm 0.01$ \\
\hline 18 & Ceylon Black Tea & $1.030 \pm 0.02$ \\
\hline 19 & Ceylon Black Tea & $1.327 \pm 0.01$ \\
\hline 20 & Turkish Green Tea & $1.470 \pm 0.01$ \\
\hline 21 & $\begin{array}{c}\text { Organic Turkish } \\
\text { Green Tea }\end{array}$ & $2.347 \pm 0.01$ \\
\hline 22 & Ceylon Green Tea & $1.010 \pm 0.05$ \\
\hline
\end{tabular}

The fluoride concentrations determined in green tea infusions were lower than those in 
black tea brews, ranging from 1.010 to 1.470 $\mathrm{mg} \mathrm{L}^{-1}$ after $10 \mathrm{~min}$ of brewing. The values obtained in this study are in agreement with those determined by Malinowski et al. (2008). Green tea is generally produced from bud with young leaves which include lower level of fluoride (Shu et al., 2003).

Regardless of tea origin and type, the amount of fluoride in the organic tea infusions was higher than that in nonorganic tea infusion. The concentrations of fluoride in the organic Turkish black and green tea infusion were $2.890 \mathrm{mg} \mathrm{L}^{-1}$ and $2.347 \mathrm{mg} \mathrm{L}^{-1}$ after $10 \mathrm{~min}$ of brewing, respectively. The amount of transfer of fluorine in the tea leaves depends on the soil composition and may be also affected by the local environmental conditions.

\section{Fluoride intake by human}

For children and teenager person the recommended safe daily $F$ intake from the all sources ranges from 1.5 to $2.5 \mathrm{mg}$ and for adult person, it is in range of $1.5-4.0 \mathrm{mg}$ (Emekli-Alturfan et al., 2009). In accordance with recommendations and considering an average consumption of five cups or ten glass $(1000 \mathrm{ml})$ per person per day, the percentage of the average daily intake of fluoride from tea extracts after $10 \mathrm{~min}$ of brewing was determined and depicted in Table 2. The fluoride intake from the daily consumption of Turkish black tea infusions could range from $48.3 \%$ to $80 \%$ for children and teenagers and from $30.2 \%$ to $50 \%$ for an adult person, respectively. In the case of Ceylon black tea infusions, the daily intake of fluoride for adult and children with five cups $(1000 \mathrm{ml})$ of their infusions can be ranged from $25.8 \%$ to $33.2 \%$ and from $41.2 \%$ to $53.1 \%$ respectively. An adult tea drinker consuming ten glasses (1000 $\mathrm{ml}$ ) of Turkish and green tea brews every day would have $\mathrm{F}$ intake in range of $58.8 \%$ and
$40.4 \%$, respectively. $\mathrm{F}$ intake from the green tea infusions for children will be $25.3 \%$ and $36.8 \%$.

Table 2. The percentage of the average daily intake of fluoride for children and teenagers, and adults (1000 $\mathrm{ml}$ per day)

Çizelge 2. Yetişkin ve çocuk bir bireyin günde $1000 \mathrm{ml}$ çay tükettiğinde günlük florür ihtiyacının karşılanma oranları

\begin{tabular}{|c|c|c|}
\hline $\begin{array}{l}\text { Sample } \\
\text { No } \\
\text { Örnek No }\end{array}$ & $\begin{array}{c}\text { Children and } \\
\text { Teenagers } \\
\text { Çocuklar ve } \\
\text { Gençler }\end{array}$ & $\begin{array}{c}\text { Adults } \\
\text { Yetişkinler }\end{array}$ \\
\hline 1 & 80.0 & 50.0 \\
\hline 2 & 66.8 & 41.8 \\
\hline 3 & 60.7 & 37.9 \\
\hline 4 & 69.7 & 43.6 \\
\hline 5 & 78.0 & 48.8 \\
\hline 6 & 67.2 & 42.0 \\
\hline 7 & 64.3 & 40.2 \\
\hline 8 & 48.3 & 30.2 \\
\hline 9 & 64.7 & 40.4 \\
\hline 10 & 77.5 & 48.4 \\
\hline 11 & 75.9 & 47.4 \\
\hline 12 & 57.1 & 35.7 \\
\hline 13 & 65.1 & 40.7 \\
\hline 14 & 65.9 & 41.2 \\
\hline 15 & 71.6 & 44.8 \\
\hline 16 & 115.6 & 72.3 \\
\hline 17 & 42.0 & 26.3 \\
\hline 18 & 41.2 & 25.8 \\
\hline 19 & 53.1 & 33.2 \\
\hline 20 & 58.8 & 36.8 \\
\hline 21 & 93.9 & 58.7 \\
\hline 22 & 40.4 & 25.3 \\
\hline
\end{tabular}

\section{Conclusions}

Tea is the most popular nonalcoholic beverage in the world. People drink a great deal of tea all day in Turkey. However, tea is known a fluoride accumulator and its consumption can contribute significantly to total fluoride intake. Fluorine is an essential element in human diet based on its important 
role in bone and teeth mineralization. On the other hand, the increased fluoride intake with food as well as an occupational exposure on fluoride dust could be a reason of the skeletal and dental fluorosis.

In general, the fluoride concentrations determined in Turkish black and green tea infusion were higher than in Ceylon black and green tea. The fluoride concentrations determined in green tea infusions were lower than those in black tea brews. The amount of fluoride in the organic tea infusions was higher than that in nonorganic tea infusion. Based on the data obtained it is concluded that consuming some tea infusions, especially black tea, in large quantities may lead to explosion to a high amount of fluoride and may increase the risk of developing dental and skeletal fluorosis.

\section{Acknowledgment}

This study was funded by the Scientific and Technological Research Council of Turkey (TUBITAK project no: 110Y234)

\section{References}

Anonymous, 2014. http://www.fao.org/statistics/en/. Access date: 07.12.2014

Anonymous, 2015. http://www.tuik.gov.tr/. Access date: 15.09.2015

APHA. 1998. Standard Methods for the Examination of Water and Wastewater, 20th edn. American Public Health Association, Washington.

Cabrera, C., Gimenez, R., Lopez, M.C. 2003. Determination of Tea Components with Antioxidant Activity. Journal of Agricultural and Food Chemistry. 51 (5): 4424-4435.
Chan, J.T., Koh, S.H., 1996. Fluoride Content in Caffeinated, Decaffeinated and Herbal Teas. Caries Research, 30: 88-92.

Chung, F.L., Schwartz, J., Herzog, C.R., Yang, Y.M. 2003. Tea and Cancer Prevention: Studies in Animals and Humans. The Journal of Nutrition, 133: 3268-3274.

Emekli-Alturfan, E., Yarat, A., Akyuz, S. 2009. Fluoride Levels in Various Black Tea, Herbal and Fruit Infusions Consumed In Turkey. Food and Chemical Toxicology, 47: 1495-1498.

Fung, K.F., Zhang, Z.Q., Wong, J.W.C., Wong, M.H. 1999. Fluoride Contents in Tea And Soil from Tea Plantations and the Release of Fluoride into Tea Liquor During Infusion. Environmental Pollution, 104: 197-205.

Hayacibara, M.F., Queiroz, C.S., Tabchoury, C.P.M., Cury, J.A., 2004. Fluoride and Aluminum in Teas and Tea-based Beverages. Revista de Saude. Publica, 38 (1): 100-105.

Karak, T., Bhagat, R.M. 2010. Trace Elements in Tea Leaves, Made Tea and Tea Infusion: A review. Food Research International, 43: 2234-2252.

Liu, H., Deng, S., Li, Z., Yu, G., Huang, J. 2010. Preparation of Al-Ce Hybrid Adsorbent and Its Application for Defluoridation of Drinking Water. Journal Hazardous Materials, 179: 424-430.

Malinowski, E., Inkielewicz, I., Czarnowski, W., Szefer P. 2008. Assesment of Fluoride Concentration and Daily Intake by Human From Tea and Herbal Infusions. Food and Chemical Toxicology, 46 (3): 1055-1061.

Shu, W.S., Zhang, Z.Q., Lan, C.Y., Wong, M.H. 2003. Fluoride and Aluminium Concentrations of Tea Plants and Tea Products from Sichuan Province, PR China. Chemosphere, 52: 1475-1482. 
Sofuoglu, S.C., Kavcar, P. 2008. An Exposure and Risk Assessment for Fluoride and Trace Metals in Black Tea. Journal Hazardous Materials, 158: 392-400.

Sucman, E., Bednar, J. 2012. Determination of Fluoride in Plant Material Using Microwave Induceed Oxygen Combustion. Czech Journal of Food Science, 30 (5): 438-441.

Wang, X.L., Liang, Y. R. 2012. Kinetics Study Ion Leaching of Fluorine from Green Tea. African Journal of Pharmacy and Pharmacology, 6 (19): 1410-1416.

Wong, M.H., Fung, K.F., Carr, H.P. 2003. Aluminium and Fluoride Contents of Tea, with Emphasis on Brick Tea and Their Health Implications, Toxicology Letters, 137: 111-120.

Yao, L.H., Jiang, Y.M., Shi, J., Tomas-Barberan, F.A., Datta, N., Singanusong, R., Chen, S.S. 2004. Flavonoids in Food and Their Health Benefits. Plant Foods for Human Nutrition, 59 (3): 113-122. 